\title{
Isolation of canCHS1A, a variant gene of Candida albicans chitin synthase
}

\author{
Masayuki Sudoh, ${ }^{1}$ Miyuki Watanabe, ${ }^{2}$ Toshiyuki Mio, ${ }^{1}$ \\ Shigehisa Nagahashi, ${ }^{1}$ Hisafumi Yamada-Okabe, ${ }^{1}$ Masamichi Takagi ${ }^{3}$ \\ and Mikio Arisawa'
}

Author for correspondence: Mikio Arisawa. Tel: +8146747 2213. Fax: +81467451675.

1,2 Departments of Mycology ${ }^{1}$ and Pharmaceutical Screening ${ }^{2}$, Nippon Roche Research Center, Kamakura-shi, Kanagawa 247, Japan

3 Department of Agricultural Chemistry, The University of Tokyo, Bunkyo-ku, Tokyo 113, Japan

\begin{abstract}
A canCHS1A gene encoding the chitin synthase of Candida albicans was cloned. DNA sequencing and comparison with another canCHS1 gene described elsewhere indicated that the canCHS1A gene encoded a polypeptide with 775 amino acid residues, a protein with one less amino acid than that encoded by the canCHS1 gene. A six-base alteration was observed between the two genes, suggesting that the canCHS1A gene is a variant gene of the canCHS1. The pH profile/activity relationship of canChs1A in permeabilized cells was identical to that of canChs1. The canChs1A enzyme was competitively inhibited by polyoxin D $(5 \cdot 2 \mu \mathrm{M})$ and nikkomycin $Z(12 \mu \mathrm{M})$. When the cloned gene was expressed in a Saccharomyces cerevisiae chs 2 mutant that exhibited aberrant morphology, the normal structure was restored. We conclude that the function of the canCHS1A gene is similar to that of sacCHS2 in S. cerevisiae.
\end{abstract}

Keywords: chitin synthase, Candida albicans, morphology

\section{INTRODUCTION}

Candida albicans is a dimorphic fungus and an opportunistic pathogen that can cause serious infections in humans, particularly in immunocompromised patients. There is a high degree of correlation between its virulence and ability to undergo morphogenesis from yeast to hyphal cell type (Soll, 1992). The hyphal form plays a major role in pathogenicity and is the form involved in tissue invasion. Among the changes observed in the yeasthyphal transition in Candida is a three- to fivefold increase in chitin levels in the cell wall of hyphae (Chattaway et al., 1968; Sullivan et al., 1983). Therefore, it is important to understand the mechanism of the primary septum formation and yeast-hyphal transition in this pathogen.

In the yeast Saccharomyces cerevisiae, there are three kinds of chitin synthase (UDP- $N$-acetyl-D-glucosamine: chitin 4$\beta$ - $N$-acetylglucosaminyltransferase, EC 2.4.1.16). Each enzyme has a specific function: chitin synthase 1 (sacChs1) is a repair enzyme (Cabib et al., 1989), counterbalancing

Abbreviations: canChs1-3, Candida albicans Chs1-3; canCHS1-3, chitin synthase gene 1-3 of Candida albicans; Chs1-3, chitin synthase 1-3; CHS1-3, chitin synthase gene 1-3; sacChs1-3, Saccharomyces cerevisiae Chs1-3; sacCHS1-2, chitin synthase gene 1-2 of Saccharomyces cerevisiae; UDP-GICNAC, UDP-N-acetylglucosamine.

The DDBJ accession number for the nucleotide sequence data reported in this paper is D43627. the activity of the chitinase; chitin synthase 2 (sacChs2) participates in the formation of the chitin ring that completes the primary septum at cytokinesis (Bulawa \& Osmond, 1990); chitin synthase 3 (sacChs3) is responsible for chitin in the ring at bud emergence and in the cell wall (Shaw et al., 1991). Of these, sacChs2 appears to be the most important chitin synthase because disruption of the yeast $C H S 2$ gene resulted in the non-viability of the yeast, though this depended on the genetic background of the strain (Bulawa \& Osmond, 1990). In aberrant microcolonies, there seems to be no completed cell divisions (Silverman et al., 1988).

The counterparts of these three chitin synthases in $S$. cerevisiae have been cloned from $C$. albicans (canChs1, canChs2 and canChs3) (Au-Young \& Robbins, 1990; Chen-Wu et al., 1992; Sudoh et al., 1993). Based on their amino acid sequence homologies, sacChs1 (Bulawa et al., 1986) and sacChs2 (Silverman, 1989) in S. cerevisiae correspond to canChs2 (Chen-Wu et al., 1992) and canChs1 (Au-Young \& Robbins, 1990) in C. albicans, respectively, and sacChs3, which is encoded by the gene designated as CAL1 (Valdivieso et al., 1991) or CSD2 (Bulawa, 1992), corresponds to canChs3 (Sudoh et al., 1993). However, there is no evidence that they functionally complement each other. The previously cloned canCHS1 gene has been isolated as a chitin synthase gene from C. albicans by complementation of the chs 1 mutant in S. cerevisiae (Au-Young \& Robbins, 1990). In this study, 
we isolated the sacChs2 counterpart from $C$. albicans (canChs1A) using the Southern hybridization method under low stringency conditions. We report here the cloning of the Candida canCHS1 $A$, which revealed a variant of the canCHS1 (Au-Young \& Robbins, 1990), and show that some enzymic properties of canChs1 $\mathrm{A}$ are similar to those of sacChs2. As expected, the expression of the canCHS1 $A$ gene complements the chitin synthase 2 mutation of $S$. cerevisiae, chs 2 .

\section{METHODS}

Strains and media. The Saccharomyces cerevisiae strains used in this study were $\mathrm{D} 3 \mathrm{C}(M A T \alpha u r a 3)$ transformed with pMS1 as the source of Chs1 (Bulawa et al., 1986) and RRA400-1U (MATa bis3 leu2 trp1 ura3 chs1::URA3 chs3::HIS3) transformed with YpLCS2 for Chs2. S. cerevisiae RRA400 (MATa bis 3 leu 2 trp1 ura3 chs 3:: HIS3) was obtained from Motoyama et al. (1994). RRA400-1U was constructed by transforming strain RRA400 and BamHI- and HindIII-digested linear plasmid YIpCS1U, which contains the UR $A 3$ gene in sacCHS1. We confirmed by Southern blotting that $S$. cerevisiae $400-1 \mathrm{U}$ harboured only the sacCHS2 gene and that sacCHS1 was disrupted by the $U R A 3$ gene (data not shown).

Yeast strains were grown in YPD $[1 \%, \mathrm{w} / \mathrm{v}$, Bacto yeast extract (Difco), $2 \%, \mathrm{w} / \mathrm{v}$, peptone (Difco), $2 \%, \mathrm{w} / \mathrm{v}$, glucose], YND $[2 \%, w / v$, glucose, $0.7 \%$ yeast nitrogen base without amino acids (Difco), nutritional requirements of amino acids], YPGal (composition as YPD except that $2 \%, \mathrm{w} / \mathrm{v}$, galactose replaced glucose) or YNGal (as YND except that $2 \%, \mathrm{w} / \mathrm{v}$, galactose replaced glucose). Transformation was achieved by the electroporation technique of either Delome (1989) or Becker \& Guarente (1990). C. albicans IFO1060 was used for the manipulation of the genomic DNA library (Sudoh et al., 1993). Escherichia coli JM109 was used for the propagation of plasmids. $E$. coli was grown in LB medium, and $50 \mu \mathrm{g}$ ampicillin $\mathrm{ml}^{-1}$ (Wako) was added where necessary. Solid medium plates contained $2 \%$ (w/v) Bacto agar (Difco).

Plasmid constructions. The $3.4 \mathrm{~kb}$ StuI fragment of the CHS1 gene from pMS1 (Bulawa et al., 1986) was blunt-ended and ligated with HincII-digested pUC119 to yield pUCS1. The $1.0 \mathrm{~kb}$ HindIII fragment of $U R A 3$ from pMS1 was blunt-ended and ligated with NcoI-digested pUCS1 to construct YIpCS1U. A YE-type plasmid, pYPR3831 (Fukuda et al., 1994), which contains the GAL1 promoter and GAPDH terminator, was digested with EcoRI, self-ligated to exclude a coding sequence and digested with BamHI and HindIII. The resulting transcription unit was cloned to pUC18 to yield PUCGAL.

A synthetic HindIII linker was ligated into the $S$ maI-digested pUCGAL vector to yield pUCGALH. To construct YpLX, we digested pUCGALH with HindIII, and a $1 \mathrm{~kb}$ fragment was ligated to HindIII-digested YEp351'. PCR amplification was performed with the Perkin-Elmer/Cetus DNA thermal cycler and GeneAmp kit (Takara). The 5'GCGGCGTCTAGAATGCACAACAT'TAACAATGG3' and 5'GCGGCGTCTAGACTAATTTAATGGATTGTG3' primers were used for the amplification of canCHS1 $A$; the 5'GACTCTAGAATGACGAGAAACCCG3' and 5'GATGCGGCATCTAGATTAGCCCT'TTTTGTGGAA3' primers were used for the amplification of sacCHS2. Thirty-five cycles consisting of a $94^{\circ} \mathrm{C} 1 \mathrm{~min}$ melting step, a $55^{\circ} \mathrm{C} 1 \mathrm{~min}$ annealing step, and a $72^{\circ} \mathrm{C} 2 \mathrm{~min}$ extension were run. These PCR products amplified for canCHS1 $A$ and sacCHS2 were digested with $X b a I$, and the $X b a I$ site of pYEUra3 (Clonetech) was inserted to construct pYEUCA1 and pYEUCS2, respectively. To construct
YpLCA1, the former PCR product was digested with $X b a I$ and ligated to the XbaI-digested YpLX plasmid.

Southern blot analysis. The total DNA content of $C$. albicans was extracted as described previously by Sudoh et al. (1993). DNA was separated by electrophoresis on an agarose gel and transferred onto Hybond-N (Amersham). Hybridization to a ${ }^{32}$ P-labelled random-primed probe was done with a rapid hybridization buffer (Amersham) at $56{ }^{\circ} \mathrm{C}$ under low stringency conditions or at $65^{\circ} \mathrm{C}$ under high stringency conditions.

DNA sequencing. DNA sequencing was done by the method of Sanger et al. (1977). The pUC18 or pUC19 derivatives were constructed with a deletion kit (Takara), or by a restriction enzyme manipulation. The United States Biochemical sequencing kit or the AutoCycle sequencing kit in combination with the ALF DNA sequencer was used for the reaction (Pharmacia).

Assay of chitin synthases. When the GAL1 promoter was to be induced, cells were cultured in $5 \mathrm{ml}$ YND medium for $2 \mathrm{~d}$. Culture $(5 \mathrm{ml})$ was inoculated into $100 \mathrm{ml}$ YND medium and cultured to $\mathrm{OD}_{660} \sim 1 \cdot 0$. The cells were collected by centrifugation, washed with YNGal medium, resuspended in $100 \mathrm{ml}$ YNGal medium, and cultured overnight. Cells $\left(1 \times 10^{8} \mathrm{ml}^{-1}\right)$ were treated with digitonin solution containing $0.5 \%$ digitonin and $20 \mathrm{mM}$ Tris $/ \mathrm{HCl}, \mathrm{pH} 7.5$, for $30 \mathrm{~min}$ at $30^{\circ} \mathrm{C}$. An appropriate trypsin concentration $\left(20 \mu \mathrm{g} \mathrm{ml}^{-1}\right.$; Sigma T-8253, type III) showing maximal chitin synthase activity was added to the permeabilized cell preparation. The optimal amount of trypsin depended on the manufacturer's lot. After a $15 \mathrm{~min}$ digestion at $30^{\circ} \mathrm{C}$, soybean trypsin inhibitor $(1.5$-fold that of the trypsin concentration) was added to each reaction tube. A $30 \mu l$ portion of the cell suspension was added to $20 \mu \mathrm{l}$ of the assay mixture. Assay conditions were as described by Sburlati \& Cabib (1986) for sacChs1 and sacChs2 and as described by AuYoung \& Robbins (1990) for canChs1 and canChs1A. For determination of the $\mathrm{pH}$ profiles, $50 \mathrm{mM}$ Tris-maleate buffer in the range $\mathrm{pH} 5 \cdot 5-8 \cdot 5$ was used as reported by Au-Young \& Robbins (1990). A portion of $10^{6}$ permeabilized cells was equivalent to $13 \mu \mathrm{g}$ protein.

Staining with Calcofluor. Calcofluor white MR2 (fluorescent brightener 28; Sigma F-6259) was used. Cells were mixed with an equal volume of $100 \mu \mathrm{g}$ Calcofluor $\mathrm{ml}^{-1}$ and held at room temperature for $1 \mathrm{~h}$. Cells were examined with an Olympus microscope equipped with epi-illumination and a $100 \mathrm{~W}$ mercury lamp.

Protein determination. Protein was measured using the BioRad DC protein assay kit with BSA as a standard.

\section{RESULTS}

\section{Isolation and DNA sequencing of canCHS1A}

When the probe with the ORF of the S. cerevisiae CHS gene was used under low stringency conditions, the Southern blots confirmed that a $S$. cerevisiae CHS2 gene (sacCHS2) homologue was present in the $C$. albicans

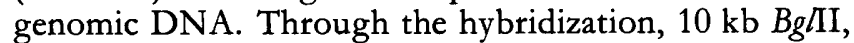
$4 \mathrm{~kb}$ EcoRI, $23 \mathrm{~kb}$ SacI, and $20 \mathrm{~kb}$ and $3.5 \mathrm{~kb} X b a \mathrm{I}$ fragments were observed at $56^{\circ} \mathrm{C}$ (Fig. 1). None of these signals were observed at $65^{\circ} \mathrm{C}$. For the isolation of the sacCHS 2 counterpart from $C$. albicans, a BglII-digested $C$. albicans genomic DNA library was constructed and screened with the use of the sacCHS2 gene under the same conditions used for the Southern hybridization. Four clones, isolated from the library, gave identical restriction 


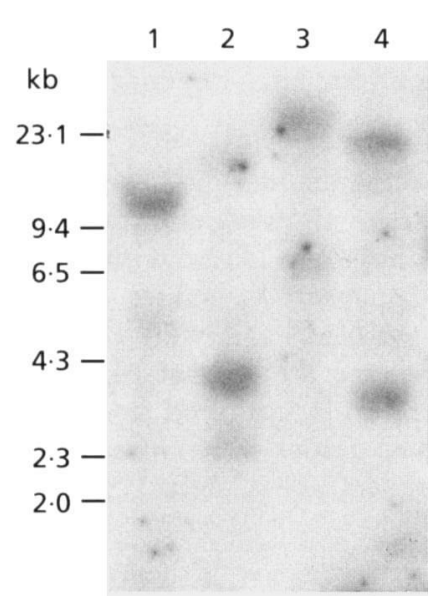

Fig. 1. Southern hybridization analysis of genomic DNA with sacCHS2 as probe. A Southern blot of total DNA from $C$. albicans IFO1060, digested with Bg/II (lane 1), EcoRI (lane 2), Sacl (lane 3), or Xbal (lane 4), was hybridized at $56{ }^{\circ} \mathrm{C}$ with the $4 \mathrm{~kb}$ HindlII-Xbal-digested sacCHS2 probe (Silverman et al., 1988), which encodes the ORF, as described in Methods. The positions and sizes of the HindIII-digested lambda DNA markers are shown.

\section{Table 1. Comparison of the ORFs of canCHS1 and canCHS1A}

Nucleotides are numbered from the first methionine codon of canCHS1 (Au-Young \& Robbins, 1990) as number 1. The canCHS1 encodes a polypeptide with 776 amino acid residues.

\begin{tabular}{|ll|}
\hline \multicolumn{1}{|c|}{ canCHS1 (2328 nt) } & canCHS1A (2325 nt) \\
\hline $\mathrm{C}$ at $1324\left(\mathrm{Leu}^{\mathbf{4 4 2}}\right)$ & $\mathrm{T}$ at $1324\left(\mathrm{Leu}^{\mathbf{4 4 2}}\right)$ \\
$\mathrm{GAA}$ from 1333 to $1335\left(\mathrm{Glu}^{\mathbf{4 4 5}}\right)$ & Deletion \\
$\mathrm{G}$ at $1503\left(\mathrm{Leu}^{501}\right)$ & $\mathrm{A}$ at $1500\left(\mathrm{Leu}^{\mathbf{5 0 0}}\right)$ \\
$\mathrm{C}$ at $2304\left(\mathrm{Tyr}^{\mathbf{7 6 8}}\right)$ & $\mathrm{T}$ at $2301\left(\mathrm{Tyr}^{\mathbf{7 6 7}}\right)$ \\
\hline
\end{tabular}

enzyme maps. Although their physical maps were nearly similar to the canCHS1 gene reported earlier (Au-Young \& Robbins, 1990), the internal partial sequence of our clone was different from that of canCHS1 (data not shown). Thus, one of the inserts, pCACS1, was sequenced. A single, continuous ORF of 2325 bases for a predicted protein of $88151 \mathrm{Da}$ was found in the $2740 \mathrm{bp}$ sequence. The nucleotide sequence has no introns in the ORF. A comparison of the nucleotide sequence of the cloned DNA fragment with the canCHS1 gene revealed that GAA, which would encode glutamic acid at positions 1333-1335 in the canCHS1 gene, was missing in our clone. Other changes included substitutions of $\mathrm{T}, \mathrm{A}$ and $\mathrm{T}$ in place of $C$ (position 1324), G (1503) and C (2304) of the canCHS1 gene, respectively, although none of these nucleotide alterations gave rise to any amino acid substitutions in the protein specified by this gene (Table 1 ). Within the canCHS1 $A$ DNA sequence confirmed, no alteration was found in $297 \mathrm{bp}$ upstream from the first ATG and 117 bp downstream from the stop codon TAG.

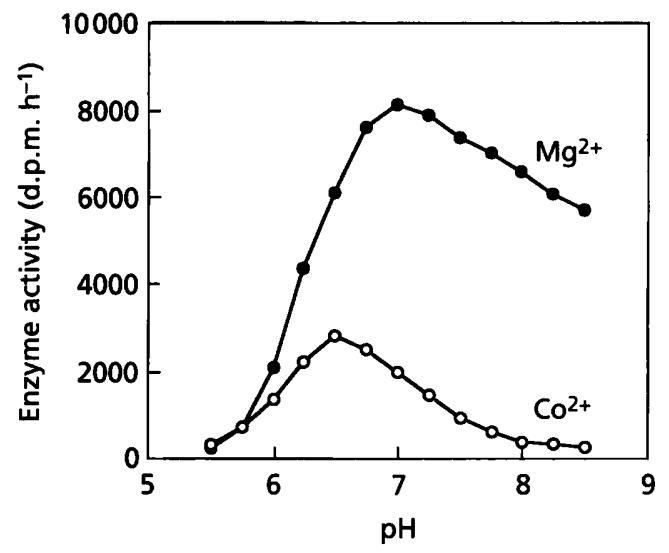

Fig. 2. pH-activity profile of the $C$ albicans chitin synthase activity expressed in $S$. cerevisiae. After trypsin treatment, digitonin-permeabilized cells $\left(10^{6}\right.$ cells, equivalent to $13 \mu \mathrm{g}$ protein) were assayed at $\mathrm{pH}$ values between 5.5-8.5 with $50 \mathrm{mM}$ Tris-maleate buffer (Au-Young \& Robbins, 1990) containing $5 \mathrm{mM}$ magnesium acetate or $2.5 \mathrm{mM}$ cobalt acetate. Digitonin-permeabilized cells are from $S$. cerevisiae RRA400-1U transformed with YpLCA1 and grown in galactose medium; $1 \mathrm{nmol}$ UDP- $\mathrm{N}$-acetyl[ $\left.{ }^{3} \mathrm{H}\right]$ glucosamine is equal to 1600 d.p.m.

Since the canCHS1 $A$ encoded a polypeptide of 775 amino acids, the protein sequence identity was $99 \%$. Therefore, canCHS1 $A$ is probably a variant gene of canCHS1.

To examine whether another canCHS1 gene is present in this strain, we carried out PCR analysis and focused on the Glu ${ }^{445}$ position. The specific primers needed for amplifying the regions from nucleotides 1089 to 1694 containing the $\mathrm{Glu}^{\mathbf{4 4 5}}$ codon were designed. The sequences of five clones derived from the PCR product were all that of canCHS1 $A$ (data not shown).

\section{Characterization of canChs1A}

We expressed the canCHS1A gene in $S$. cerevisiae cells by using the GAL1 promoter to examine whether or not the protein specified by this gene was chitin synthase. Since chitin is synthesized at a rapid rate in digitoninpermeabilized cells supplied with UDP- $N$-acetylglucosamine (UDP-GlcNAc) (Fernandez et al., 1982), these were used in our assays. Chitin synthase activity of RRA400-1U under these assay conditions was at background level and, therefore, the endogenous Chs 2 levels were negligible. When YpLCA1, a plasmid carrying the canCHS1A gene whose transcription was under the control of the GAL1 promoter, was introduced into this strain, a significant level of chitin synthase activity was detected, and this activity was completely dependent on galactose. In contrast, these same cells cultured in medium containing glucose showed no activity, compared with those transfected with the vector control (data not shown). The expressed canChs1 A was also zymogenic, as are sacChs 1 and sacChs2; trypsin treatment of the protein activated the enzyme activity approximately tenfold. The $\mathrm{pH}$-activity profiles of canChs1A expressed in strain RRA400-1U are shown in Fig. 2. The apparent $\mathrm{pH}$ optimum of the $C$. albicans chitin synthase activity was $6 \cdot 8$ 

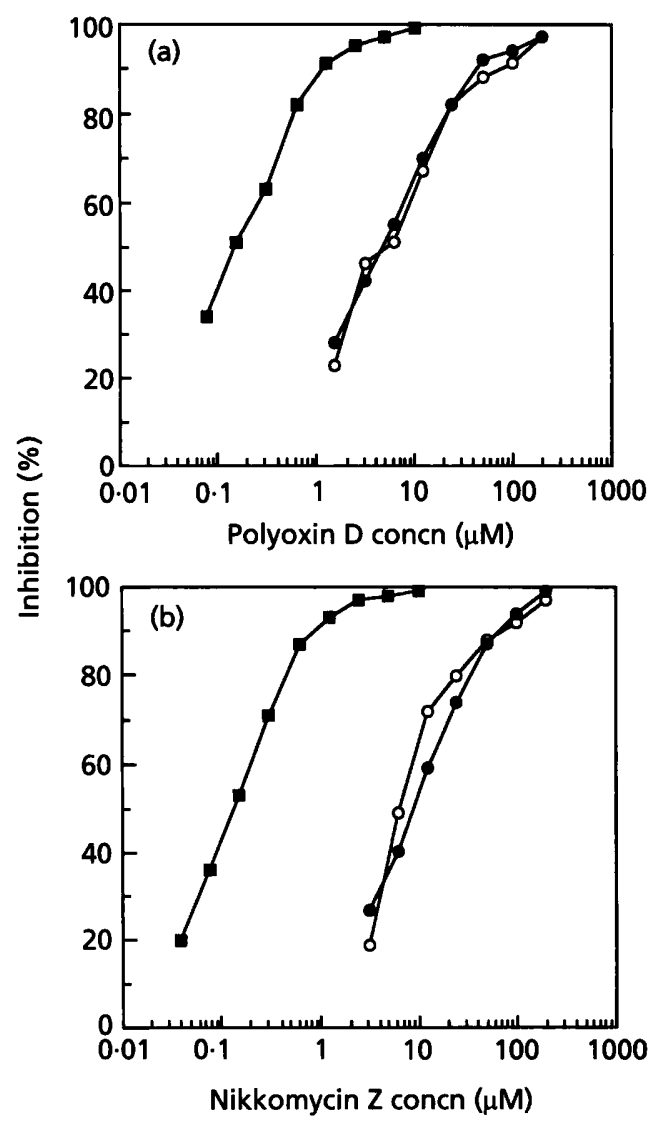

Fig. 3. Inhibition of $S$. cerevisiae Chs1 ( $)$, Chs2 (O) and canChs $1 \mathrm{~A}(\mathrm{O})$ by polyoxin D (a) and nikkomycin Z (b); $10^{6}$ cells were used.

when $\mathrm{Mg}^{2+}$ was present. On the other hand, with $\mathrm{Co}^{2+}$, the optimal activity shifted to acidic $\mathrm{pH} 6.5$. In this case, the activity was reduced to $37 \%$ of the total activity. The activity of canChs1 A was greater with the $\mathrm{Mg}^{2+}$ cation than with the $\mathrm{Co}^{2+}$ cation; for $S$. cerevisiae the activity was reversed. Therefore, the $\mathrm{pH}$ profile of canChs1A was almost similar to another canChs 1 described by AuYoung \& Robbins (1990).

We examined the effects of the chitin synthase inhibitors polyoxin D and nikkomycin Z. As a control, S. cerevisiae chitin synthase activity was measured in the presence of the cation that yields the greatest activity: $\mathrm{Mg}^{2+}$ for sacChs1 and $\mathrm{Co}^{2+}$ for sacChs2 (Sburlati \& Cabib, 1986). Under these conditions, both polyoxin $\mathrm{D}$ and nikkomycin $\mathrm{Z}$ were more inhibitory for sacChs1 than for sacChs2 (Fig. 3). Inhibitory patterns of sacChs1 with $\mathrm{Mg}^{2+}$, canChs1A with $\mathrm{Mg}^{2+}$ and sacChs 2 with $\mathrm{Co}^{2+}$ were compared. The $C$. albicans Chs1A had almost the same inhibitory pattern as that of sacChs2 (Fig. 3). sacChs1 was strongly inhibited by polyoxin $\mathrm{D}$ and nikkomycin $\mathrm{Z}$, whereas canChs1 $\mathrm{A}$ and sacChs2 were somewhat less sensitive to these inhibitors. The difference in the responses of these drugs (between $50-100$-fold) demonstrates that the drug sensitivity of
canChs1 A is similar to that of sacChs2, even though the activities of these enzymes depended on cation requirements.

Kinetic measurements in which the substrate concentration was varied showed competitive inhibition for canChs1 A with polyoxin D and with nikkomycin $\mathrm{Z}$ (data not shown). Apparent $K_{\mathrm{i}}$ values of polyoxin $\mathrm{D}$ and nikkomycin $\mathrm{Z}$ for canChs1A were approximately $5 \cdot 2 \mu \mathrm{M}$ and $12 \mu \mathrm{M}$, respectively. Dixon plot analysis indicated that both compounds inhibited competitively and that their calculated $K_{\mathrm{i}}$ values were closer to those of sacChs 2 than to those of sacChs1 (Cabib, 1991).

\section{Complementation of the S. cerevisiae chs 2 mutation}

To address the canCHS1 $A$ functions in S. cerevisiae in vivo, we used a low-copy vector and galactose inducible expression plasmid carrying a canCHS1 $A$. The presumed ORF of canCHS1 $A$ was amplified by PCR using specific primers and cloned into the $X b a \mathrm{I}$ site of the expression plasmid pYEUra3. The resulting pYEUCA1 was transformed into S. cerevisiae $4992 \mathrm{H}$ and $5002 \mathrm{H}$, which were $c h s 2$-deficient mutants derived from YPH499 and YPH500 whose mating types are $M A T \mathbf{a}$ and $\alpha$, respectively. For our control, the sacCHS2 gene was similarly amplified and cloned into pYEUra3 to yield pYEUCS2. The plasmid was stably segregated in these strains even when grown in a complete medium. Transformation of $4992 \mathrm{H}$ or $5002 \mathrm{H}$ cells with pYEUCA1 or pYEUCS2 did not alter the morphology of these cells unless they were cultured in galactose-containing medium (Fig. 4a, e). Buds had formed, and a daughter cell had not separated from the mother cell. Calcofluor, which specifically binds to $1,4-\beta$ linked polysaccharides and stains the boundary between mother and daughter cells, did not distinguish the boundary between the mother and daughter cells of the chs 2 mutant (Fig. 4e). After bud emergence, cells with normal morphology lost the ability to form chitin at the budding site (data not shown). These findings show that the $c h s 2$ mutation of $S$. cerevisiae is lacking in both septum formation and cell division as previously reported by Silverman et al. (1988). When $4992 \mathrm{H}$ cells harbouring pYEUCA1 or pYEUCS2 were cultured in the medium containing galactose, both transformants showed normal morphology and underwent regular budding, which was confirmed by Calcofluor staining of the budding site (Fig. $4 \mathrm{f}$, demonstrating that both sacCHS2 or canCHS1A genes were equally capable of rescuing a chs 2 mutation. Further, the functional complementation of the sacCHS2 gene by the canCHS1 $A$ gene was totally independent of the mating type because induction of canCHS1 $A$ gene in $5002 \mathrm{H}$ cells whose mating type was $\alpha$ by galactose also resulted in the normal phenotype and budding (Fig. 4c, d).

\section{DISCUSSION}

We succeeded in identifying a homologue of $S$. cerevisiae from $C$. albicans by Southern blot analysis under low 

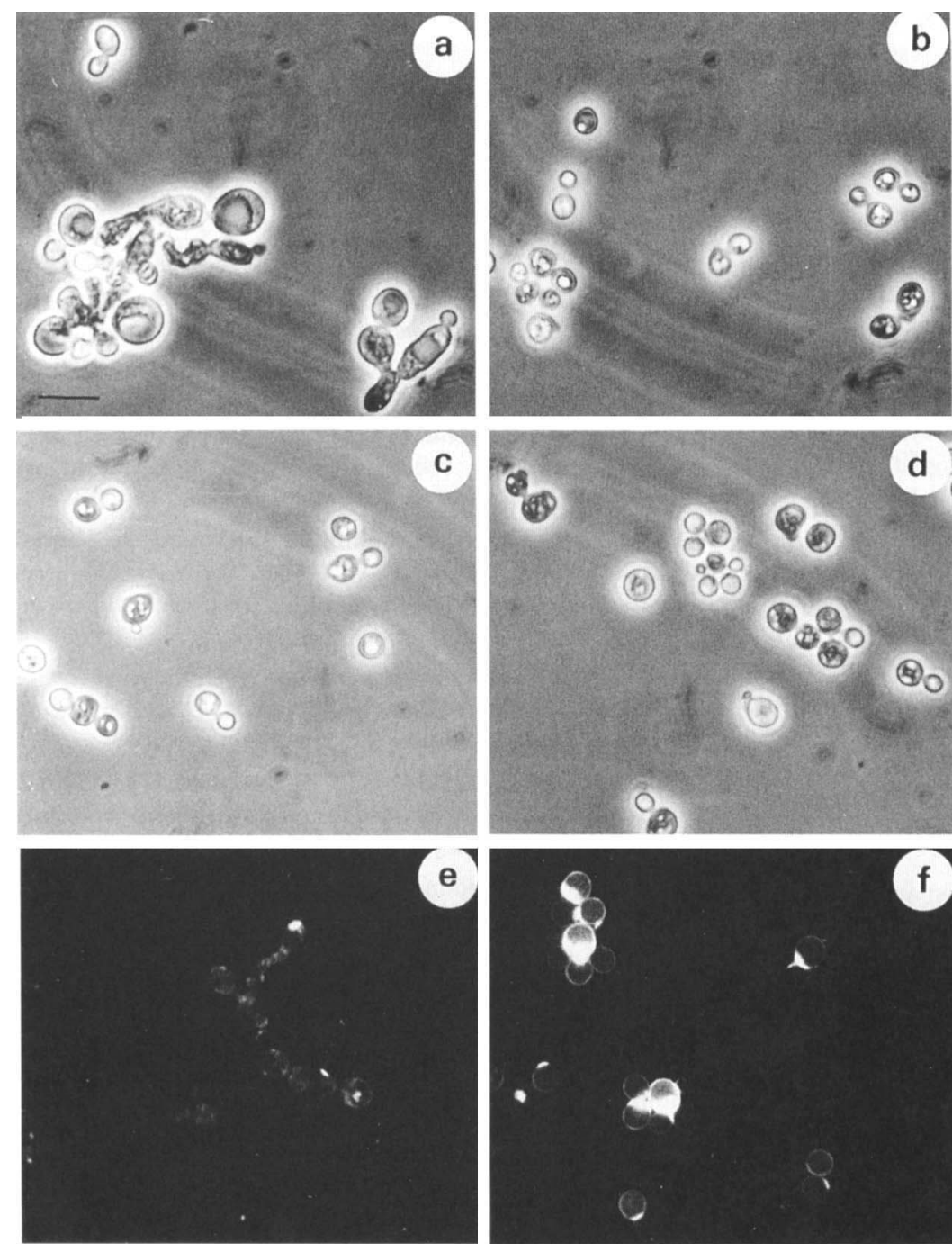

Fig. 4. Complementation of cell morphology in strains which express the canCHS1A gene. Cells of the chs2::HIS3 mutant were transformed with pYEUCS2 or pYEUCA1 and grown in glucose or galactose, and then examined with a phase contrast microscope (a-d) or stained with Calcofluor and observed with a fluorescence microscope (e, f). Strain $4992 \mathrm{H}$ transformed with pYEUCS2 was grown in glucose (a) and in galactose (b). Strains $4992 \mathrm{H}$ and $5002 \mathrm{H}$ were transformed with PYEUCA1 and grown in galactose (c, d). Cells of strain $4992 \mathrm{H}$ without the expression of the canCHS1A gene in glucose medium are shown in (e) and with the expression in galactose medium in (f). Bar, $10 \mu \mathrm{m}$.

stringency conditions. The deduced protein of the gene cloned in this study was compared with another canCHS1 (Au-Young \& Robbins, 1990). There were several base alterations in those genes but minor base alterations did not affect the amino acid sequence. The canChs1 A protein is missing one amino acid at the $\mathrm{Glu}^{445}$ position of nucleotide 1629 , but this is unlikely to be a critical region since it is not located in the consensus region of chitin synthases (Bowen et al., 1992). The differences in these sequences may be the result of differences at the strain level. Therefore, the canCHS1 $A$ gene seems to be a variant gene of $C$. albicans chitin synthase (Au-Young \& Robbins, 1990). The PCR analysis was targeted to screen another chitin synthase gene by amplification of the $\mathrm{Glu}^{445}$ region. We failed to find any other sequence besides the canCHS1 $A$ type, suggesting that the canCHS1 type sequence is not present in the $C$. albicans IFO1060 strain.

In order to characterize the enzymic properties of canChs1A, we analysed a yeast strain expressing the
canCHS1 $A$ gene. The optimal $\mathrm{pH}$ range of canChs1A was neutral when the best activating cation $\left(\mathrm{Mg}^{2+}\right)$ was used, whereas the optimum shifted slightly to an acidic $\mathrm{pH}$ when $\mathrm{Co}^{2+}$ was used. It is unclear why significant changes in the optimal $\mathrm{pH}$ depend on the use of a particular cation in the assay. The $\mathrm{pH}$ profiles were similar to those described for canChs1 (Au-Young \& Robbins, 1990). The $K_{\mathrm{m}}$ value for UDP-GlcNAc was $0.4 \mathrm{mM}$ for canChs1A with $\mathrm{Mg}^{2+}$ (data not shown), in good agreement with the values reported for other chitin synthases; $0.5 \mathrm{mM}$ for sacChs1 with $\mathrm{Mg}^{2+}, 0.65 \mathrm{mM}$ for sacChs2 with $\mathrm{Co}^{2+}$, and $0 \cdot 28 \mathrm{mM}$ for sacChs 2 with $\mathrm{Mg}^{2+}$ (Cabib, 1991).

The drug sensitivity of canChs1A was tested against polyoxin $\mathrm{D}$ and nikkomycin $\mathrm{Z}$, both of which are potent competitive chitin synthase inhibitors. sacChs 1 was strongly inhibited by both inhibitors, whereas canChs1 A and sacChs 2 were similarly inhibited, but were $50-100$ times less sensitive to both inhibitors. The sensitivity of sacChs 2 in permeabilized cells corresponded to the results 
of experiments by Cabib (1991), in which a mixed membrane fraction of chitin synthase was used. This result shows that canChs1A has the same responses and mode of action to these inhibitors. Although both drugs seem to react differently in the active sites of the two enzymes sacChs1 and sacChs2 (Cabib, 1991), it is supposed that the spatial construction of the active site of canChs1 and sacChs 2 is similar. It is difficult to explain the difference in metal ion requirements, but it may depend on the environment of the active site. Based on the amino acid sequence homology, the CHS1 gene of $C$. albicans shows homology to the CHS2 gene of S. cerevisiae (AuYoung \& Robbins, 1990). The homology is emphasized by maximal parsimony similarity analysis using full-length chitin synthase polypeptides (Beth Din \& Yarden, 1994).

The canCHS1 $A$ gene product seems to function in the $S$. cerevisiae chs 2 mutant lacking the ability to form septa and to participate in cell division. This is supported by evidence showing normal budding and cell morphology in mutants that had the canCHS1 $A$ gene expressed when a controllable promoter such as GAL1 was used. This was also observed by staining with the fluorescent dye Calcofluor, strongly suggesting that the canCHS1 $A$ gene complements the chs 2 null mutation of $S$. cerevisiae.

In $S$. cerevisiae, Chs 2 is thought to be the most important chitin synthase among the three because disruption of the sacCHS2 gene results in the most severe defect in cell growth. Since canCHS1 $A$ in $C$. albicans shares high sequence similarity to sacCHS2, it is thought to be the counterpart of sacCHS2. Since we could demonstrate that the canCHS1A gene functionally complements the sacCHS2 gene, the above hypothesis is strongly supported. The real function of the canCHS1 gene in $C$. albicans cells still remains to be clarified; however, Gow (1994) has proposed that the homozygous disruption of the canCHS1 gene might be lethal. This suggests that sacCHS2 and canCHS1 have different functions in each organism because the null mutation of the sacCHS2 gene in $S$. cerevisiae did not result in the lethal phenotype (Bulawa \& Osmond, 1990). However, canChs1A also shared a somewhat higher sequence similarity with canChs2 (43\% identical) whereas canChs 3 is not quite identical to canChs1A $(25 \%)$. Thus, it would be of interest to examine whether or not canCHS2 genes also functionally complement the sacCHS2 gene. However, attempts to express canCHS2 in $S$. cerevisiae have been unsuccessful to date (Chen-Wu et al., 1992).

\section{ACKNOWLEDGEMENTS}

We thank Hisao Shimada, Neil Gow and Sanford Silverman for their helpful discussions.

\section{REFERENCES}

Au-Young, J. \& Robbins, P. W. (1990). Isolation of a chitin synthase gene (CHS1) from Candida albicans by expression in Saccharomyces cerevisiae. Mol Microbiol 4, 197-207.
Becker, D. M. \& Guarente, L. (1990). High efficiency transformation of yeast by electroporation. Methods Enzymol 194, 182-186.

Beth Din, A. B. \& Yarden, O. (1994). The Neurospora crassa chs-2 gene encodes a non-essential chitin synthase. Microbiology 140, 2189-2197.

Bowen, A. R., Chen-Wu, J. L., Momany, M., Young, R., Szaniszlo, P. J. \& Robbins, P. W. (1992). Classification of fungal chitin synthases. Proc Natl Acad Sci US A 89, 519-523.

Bulawa, C. E. (1992). CSD2, CSD3, and CSD4, genes required for chitin synthesis in Saccharomyces cerevisiae: the CSD2 gene product is related to chitin synthase and to developmentally regulated proteins in Rbizobium species and Xenopus laevis. Mol Cell Biol 12, 1764-1776.

Bulawa, C. E. \& Osmond, B. C. (1990). Chitin synthase I and chitin synthase II are not required for chitin synthesis in vivo in Saccharomyces cerevisiae. Proc Natl Acad Sci US A 87, 7424-7428.

Bulawa, C. E., Slater, M., Cabib, E., Au-Young, J., Sburlati, A., Adair, W. L., Jr \& Robbins, P. W. (1986). The S. cerevisiae structural gene for chitin synthase is not required for chitin synthase in vivo. Cell 46, 213-225.

Cabib, E. (1991). Differential inhibition of chitin synthases 1 and 2 from Saccharomyces cerevisiae by polyoxin D and nikkomycins. Antimicrob Agents Chemother 35, 170-173.

Cabib, E., Sburlati, A., Bowers, B. \& Silverman, S. J. (1989). Chitin synthase 1 , an auxiliary enzyme for chitin synthesis in Saccharomyces cerevisiae. J Cell Biol 108, 1665-1672.

Chattaway, F. W., Holmes, M. R. \& Barlow, A. J. E. (1968). Cell wall composition of the mycelial and blastospore forms of Candida albicans. J Gen Microbiol 51, 367-376.

Chen-Wu, J. L., Zwicker, J., Bowen, A. R. \& Robbins, P. W. (1992). Expression of chitin synthase genes during yeast and hyphal growth phases of Candida albicans. Mol Microbiol 6, 497-502.

Delome, E. (1989). Transformation of Saccharomyces cerevisiae by electroporation. Appl Environ Microbiol 55, 2242-2246.

Fernandez, M. P., Correa, J. U. \& Cabib, E. (1982). Activation of chitin synthase in permeabilized cells of a Saccharomyces cerevisiae mutant lacking proteinase B. J Bacteriol 152, 1255-1264.

Fukuda, R., Horiuchi, H., Ohta, A. \& Takagi, M. (1994). The prosequence of Rbizopus niveus aspartic proteinase-I supports correct folding and secretion of its mature part in Saccharomyces cerevisiae. $J$ Biol Cbem 269, 9556-9561.

Gow, N. A. R. (1994). Growth and guidance of the fungal hypha. Microbiology 140, 3193-3205.

Motoyama, T., Sudoh, M., Horiuchi, H., Ohta, A. \& Takagei, M. (1994). Isolation and characterization of two chitin synthase genes of Rbizopus oligosporus. Biosci Biotech Biochem 58, 1685-1693.

Sanger, F., Nicklen, S. \& Coulson, A. R. (1977). DNA sequencing with chain-terminating inhibitors. Proc Natl Acad Sci US A 74, 5463-5467.

Sburlati, A. \& Cabib, E. (1986). Chitin synthase 2, a presumptive participant in septum formation in S. cerevisiae. J Biol Chem 261, 15147-15152.

Shaw, J., Mol, P. C., Bowers, B., Silverman, S. J., Valdivieso, M. H., Duran, A. \& Cabib, E. (1991). The function of chitin synthase 2 and 3 in the Saccharomyces cerevisiae cell cycle. J Cell Biol 114, 111-123.

Silverman, S. J. (1989). Similar and different domains of chitin synthases 1 and 2 of $S$. cerevisiae: two isozymes with distinct functions. Yeast 5, 459-467.

Silverman, S. J., Sburlati, A., Slater, M. L. \& Cabib, E. (1988). Chitin synthase 2 is essential for septum formation and cell division in Saccharomyces cerevisiae. Proc Natl Acad Sci USA 85, 4735-4739. 
Soll, D. R. (1992). High-frequency switching in Candida albicans. Clin Microbiol Rev 5, 183-203.

Sudoh, M., Nagahashi, S., Doi, M., Ohta, A., Takagi, M. \& Arisawa, M. (1993). Cloning of the chitin synthase 3 gene from Candida albicans and its expression during yeast-hyphal transition. Mol \& Gen Genet 241, 351-358.

Sullivan, P. A., Yin, C. Y., Molloy, C. \& Templeton, M. D. (1983).

An analysis of the metabolism and cell wall composition of
Candida albicans during germ tube formation. Can J Microbiol 29, 1514-1525.

Valdivieso, M. H., Mol, P. C., Shaw, J. A., Cabib, E. \& Duran, A. (1991). $C A L 1$, a gene required for activity of chitin synthase 3 in Saccharomyces cerevisiae. J Cell Biol 114, 101-109.

Received 27 February 1995; revised 30 May 1995; accepted 21 June 1995. 